\title{
GARS wt Allele
}

National Cancer Institute

\section{Source}

National Cancer Institute. GARS wt Allele. NCI Thesaurus. Code C132128.

Human GARS wild-type allele is located in the vicinity of $7 p 14.3$ and is approximately $39 \mathrm{~kb}$ in length. This allele, which encodes glycine-tRNA ligase protein, is involved in the synthesis of glycyl-tRNA. Mutation of the gene is associated with type 2D CharcotMarie-Tooth disease and distal hereditary motor neuropathy, type $\mathrm{Va}$. 